\title{
Porównanie hałasu panującego we wnętrzu wybranych typów pojazdów szynowych podczas jazdy
}

\begin{abstract}
$W$ artykule przedstawione zostanq wyniki pomiarów hałasu zarejestrowanego we wnętrzu wybranych typów pojazdów szynowych podczas jazdy. Ocenie poddano nastęujace pojazdy: lokomotywy elektryczne, wagony pasażerskie oraz wagony tramwajowe. Ponadto dokonano przegladu aktualnych przepisów pranych z zakresu pomiaru i oceny hatasu generowanego przez szynowe środki transportu. Istniejace akty prane podzielono na dwie grupy: pierwsza grupa dotyczy przepisów zwiazanych z ocenq hałasu w środowisku. Przepisy te wydawane sa przez Ministra Środowiska i dotycza zagadnień zwiqzanych z ksztaltowaniem odpowiedniego klimatu akustycznego terenów. Druga grupa przepisów określajaca kryteria, które warunkuja dopuszczenie pojazdów szynowych do ruchu. Przepisy te wydawane sa przez Ministra Infrastruktury oraz Instytucje zwiqzane z pojazdami szynowymi.
\end{abstract}

\section{Wprowadzenie}

Hałas komunikacyjny to obecnie jeden $\mathrm{z}$ najbardziej rozpowszechnionych i dominujących źródeł hałasu. Problemy związane $\mathrm{z}$ zakłócaniem środowiska przez poruszające się drogowe i szynowe środki transportu szczególnie w pobliżu dużych aglomeracji miejskich nabierają coraz większego znaczenia wobec wzrostu liczby pojazdów samochodowych przypadających na jednego mieszkańca, eksploatacją tramwajów szczególnie w centach miast o bardzo gęstej zabudowie oraz działaniami zmierzającymi do zwiększania dopuszczalnej prędkości jazdy na kolei. Szacuje się, że przejazd tramwaju z prędkością $50 \mathrm{~km} / \mathrm{h}$ odległości 7,5 m od osi toru na wysokości $1,2 \mathrm{~m}$ powyżej główki szyny powoduje przekroczenie poziomu $80 \mathrm{~dB}$ [1]. Natomiast przejazd pociagu pasażerskiego i towarowego z prędkościami nie przekraczającymi $100 \mathrm{~km} / \mathrm{h}$ prowadzi do generowania około $90 \mathrm{~dB}$ [11].

Obecnie warunkiem dopuszczenia każdego pojazdu szynowego do eksploatacji jest spełnienie przez pojazd tylko norm związanych $\mathrm{z}$ emisją hałasu zewnętrznego. Kwestie związane $\mathrm{z}$ oceną hałasu wewnątrz pojazdów szynowych za wyjątkiem hałasu na stanowisku pracy są pomijane i nie są brane pod uwagę podczas badań nowego i istniejącego już taboru.

$\mathrm{W}$ artykule przedstawione zostaną wyniki pomiarów hałasu we wnętrzu wybranych typów pojazdów szynowych podczas jazdy. Oceniono klimat akustyczny panujaccy w kabinie maszynisty lokomotyw elektrycznych, w wagonach pasażerskich oraz wagonach tramwajowych. Ponadto dokonano przeglądu wybranych przepisów związanych $\mathrm{z}$ oceną hałasu $\mathrm{w}$ pojazdach szynowych.
2. Wybrane przepisy odnoszące się do wykonywania i oceny hałasu pojazdów szynowych w środowisku

Podstawowym aktem prawnym w zakresie ochrony środowiska w Polsce, w tym także w odniesieniu do zagadnień związanych z oceną klimatu akustycznego jest ustawa z 27 kwietnia 2001 r Prawo Ochrony Srodowiska. Ustawa ta wprowadza obowiązek wykonywania okresowej oceny stanu akustycznego środowiska dla określonych terenów położonych w obrębie aglomeracji i w sąsiedztwie obiektów komunikacyjnych. W zakresie oceny hałasu w środowisku związanej z eksploatacją szynowych środków transportu do najważniejszych można zaliczyć:

- Rozporządzenie Ministra Środowiska z dnia 14 czerwca $2007 \mathrm{r}$ w sprawie dopuszczalnych poziomów hałasu w środowisku.

- Rozporządzenie Ministra Środowiska z dnia 16 czerwca $2011 \mathrm{r}$ w sprawie wymagań w zakresie prowadzenia pomiarów poziomów substancji lub energii w środowisku przez zarządzającego drogą, linią kolejową, linią tramwajową, lotniskiem lub portem.

Rozporządzenie Ministra Środowiska w sprawie dopuszczalnych poziomów halasu w środowisku określa dopuszczalne poziomy hałasu w środowisku w zależności od pory dnia i rodzaju zagospodarowania terenu [6]. W tabeli 1 przedstawiono poziomy dopuszczalne hałasu w środowisku w odniesieniu do lądowych środków transportu.

Rozporządzenie Ministra Środowiska w sprawie wymagań $w$ zakresie prowadzenia pomiarów poziomów substancji lub energii w środowisku przez 
zarządzającego drogą, linią kolejową, linią tramwajową, lotniskiem lub portem określa wymagania $\mathrm{w}$ zakresie prowadzenia pomiarów poziomów dźwięku w środowisku przez zarządzającego drogą, linią kolejową, linią tramwajowa, lotniskiem lub portem. W zakresie pomiarów hałasu generowanego przez szynowe środki transportu rozporządzenie zaleca wykonywanie okresowych pomiarów hałasu dla linii kolejowych o natężeniu powyżej 30 tys. pociagów rocznie, a dla linii tramwajowych na odcinkach torowisk o natężeniu ruchu powyżej 100 tramwajów na dobę.

Do oceny hałasu pojazdów szynowych w środowisku dedykowana jest procedura pomiarów poziomów ekspozycyjnych dźwięku w odniesieniu do pojedynczych zdarzeń akustycznych. Procedura ta polega na łączeniu w klasy przejazdów poszczególnych typów pojazdów szynowych i rejestrowanie ekspozycyjnego poziomu dźwięku. W odniesieniu do pociagów rozporządzenie zaleca wyznaczenie minimum czterech klas pojedynczych zdarzeń akustycznych z podziałem na: pociagi pasażerskie dalekobieżne, pociaggi pasażerskie lokalne lub regionalne, pociagi towarowe i autobusy szynowe. W przypadku wykonywania pomiarów hałasu $\mathrm{w}$ środowisku związanych $\mathrm{z}$ oceną hałasu tramwajowego ilość klas pojedynczych zdarzeń akustycznych zależy od ilości typów tramwajów przejeżdżających przez dany punkt pomiarowy. Na podstawie zmierzonych ekspozycyjnych poziomów dźwięku poszczególnych typów pojazdów wyznacza się równoważny poziom dźwięku.

Punkty pomiarowe do oceny hałasu w środowisku lokalizuje się w odległości od 0,5 do $2 \mathrm{~m}$ od elewacji budynku w świetle okna kondygnacji eksponowanej na hałas lub na wysokości $4 \mathrm{~m}$ nad powierzchnią terenu, gdy nie ma możliwości wykonania pomiarów hałasu na danej kondygnacji. W przypadku gdy celem pomiarów jest ocena źródła hałasu punkt pomiarowy należy zlokalizować w następujących odległościach: $25 \mathrm{~m}$ od osi toru dla linii kolejowych i 7,5 m dla torowisk tramwajowych. Podczas wykonywania pomiarów hałasu rozporządzenie zaleca, aby wszystkie pomiary wykonywać z zachowaniem następujących warunków meteorologicznych: temperatura od $-10 \mathrm{C}$ do $50 \mathrm{C}$, wilgotność względna od $25 \%$ do $98 \%$, prędkość wiatru w zakresie $0 \div 5 \mathrm{~m} / \mathrm{s}$, ciśnieniu atmosferycznym od $900 \mathrm{hPa}$ do $1100 \mathrm{hPa}$ i braku opadów atmosferycznych [9].

\section{Przepisy związane z dopuszczeniem pojazdów szynowych do eksploatacji}

W zakresie oceny hałasu związanej z dopuszczeniem pojazdu szynowego do eksploatacji można wyróżnić następujące przepisy:

- PN-EN ISO 3095 Kolejnictwo. Akustyka. Pomiar hałasu emitowanego przez pojazdy szynowe.

- PN-EN ISO 3381 Kolejnictwo. Akustyka. Pomiar hałasu wewnątrz pojazdów szynowych.

- PN-K-11000:1992 Tabor kolejowy-Hałas Ogólne wymagania i badania.

- Transeuropejski System Kolei Konwencjonalnych Techniczna Specyfikacja Interoperacyjności Podsystem Tabor kolejowy dla kolei konwencjonalnych Zakres hałas Aspekt hałas emitowany przez wagony towarowe, lokomotywy, zespoły trakcyjne oraz wagony pasażerskie.

- Rozporządzenie Ministra Infrastruktury z dnia 28 stycznia $2011 \mathrm{r}$ w sprawie zakresu, warunków, terminów i sposobu przeprowadzania badań technicznych tramwajów i trolejbusów oraz jednostek wykonujących te badania.

Dopuszczalne poziomy hałasu w środowisku związane z eksploatacją lądowych środków transportu w odniesieniu do jednej doby [6]

Tabela 1

\begin{tabular}{|c|c|c|c|}
\hline \multirow[b]{3}{*}{ Lp. } & \multirow[b]{3}{*}{ Rodzaj terenu } & \multicolumn{2}{|c|}{ Dopuszczalny poziom hałasu w $[\mathrm{dB}]$} \\
\hline & & \multicolumn{2}{|c|}{ Drogi lub linie kolejowe, tramwajowe } \\
\hline & & $\begin{array}{c}L_{A e q} D \\
\text { Przedział czasu } \\
\text { odniesienia równy } \\
16 \text { godzinom }\end{array}$ & $\begin{array}{c}L_{\text {Aeq } N} \\
\text { Przedział czasu } \\
\text { odniesienia równy } 8 \\
\text { godzinom }\end{array}$ \\
\hline 1. & $\begin{array}{l}\text { a). strefa ochronna A uzdrowiska } \\
\text { b). tereny szpitali poza miastem }\end{array}$ & 50 & 45 \\
\hline 2. & $\begin{array}{l}\text { a). Tereny zabudowy mieszkaniowej jednorodzinnej } \\
\text { b). Tereny zabudowy związanej ze stałym lub czasowym } \\
\text { pobytem dzieci i młodzieży } \\
\text { c). Tereny domów opieki społecznej } \\
\text { d). Tereny szpitali w miastach }\end{array}$ & 55 & 50 \\
\hline 3. & $\begin{array}{l}\text { a). Tereny zabudowy mieszkaniowej wielorodzinnej i za- } \\
\text { mieszkania zbiorowego } \\
\text { b). tereny zabudowy zagrodowej } \\
\text { c). tereny rekreacyjno-wypoczynkowe } \\
\text { d) Tereny mieszkaniowo-usługowe }\end{array}$ & 60 & 50 \\
\hline 4. & $\begin{array}{l}\text { Tereny w strefie śródmiejskiej miast powyżej } 100 \text { tys. } \\
\text { mieszkańców }\end{array}$ & 65 & 55 \\
\hline
\end{tabular}


- Rozporządzenie Ministra Infrastruktury z dnia 2 marca $2011 \mathrm{r}$ w sprawie warunków technicznych tramwajów i trolejbusów oraz zakresu ich niezbędnego wyposażenia.

PN-EN ISO 3381 Kolejnictwo. Akustyka. Pomiar hałasu wewnątrz pojazdów szynowych. Norma ta określa warunki i metodyki pomiaru hałasu wewnątrz pasażerskich wagonów pojazdów szynowych oraz na stanowisku pracy maszynisty podczas jazdy i na postoju. Zawarte w dokumencie wytyczne pomiaru hałasu mają zastosowanie dla pojazdów nowych oraz już istniejących. Pomiary hałasu wewnątrz wagonów powinny być poprzedzone pomiarem tła akustycznego oraz przeprowadzone dla czterech przypadków: dla przejazdu badanych pojazdów szynowych ze stała prędkością, podczas fazy przyspieszania i hamowania oraz na postoju.

Punkty pomiarowe powinny być rozmieszczone w różnych miejscach wagonu. Zaleca się aby ich liczba wynosiła od 5 do 7 punktów pomiarowych. Przykładowe rozmieszczenie punktów pomiaru hałasu w wagonach pasażerskich przedstawia rysunek 1 .
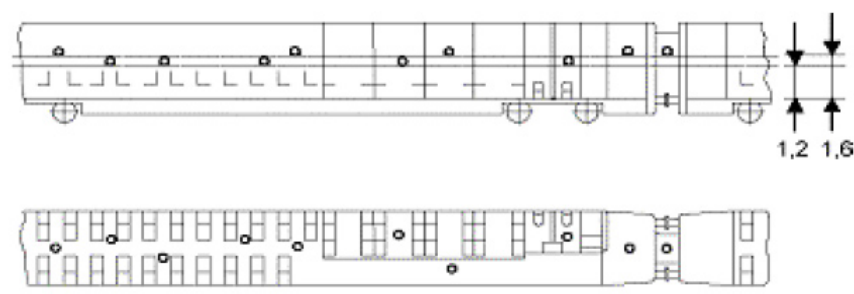

Rys. 1 Rozmieszczenie punktów pomiarowych w wagonie na dwóch wysokościach 1,2 i 1,6 m [4]

Norma zaleca wykonanie pomiarów hałasu na trzech wysokościach: 1,2 $\mathrm{m}$ i 1,6 $\mathrm{m}$ na poziomem podłogi oraz $0,2 \mathrm{~m}$ nad poziomem poduszki w przypadku pomiarów hałasu w wagonach $\mathrm{z}$ miejscami do spania. Pomiary na wysokości $1,2 \mathrm{~m}$ dotyczą pomiarów dla miejsc siedzących a pomiary na wysokości $1,6 \mathrm{~m}$ są związane z oceną hałasu dla miejsc stojących.

W przypadku oceny hałasu na stanowisku pracy maszynisty mikrofon pomiarowy powinien znajdować się na wysokości $1,6 \mathrm{~m}$ nad podłoga przy stanowisku pracy na wysokości ucha operatora $\mathrm{w}$ odległości około $0,1 \mathrm{~m}$ od ucha maszynisty.

Podczas wykonywania pomiarów powinny być spełnione następujące warunki: wszystkie pomiary należy wykonać bez pasażerów, okna i drzwi w badanych wagonach powinny być zamknięte. $\mathrm{W}$ przypadku nowych wagonów należy wykonać w trzy serie pomiarowe natomiast dla badań kontrolnych wystarczy jeden pomiar. Wielkościami rejestrowanymi są następujące wielkości: równoważny poziom dźwięku skorygowany charakterystyką A $\left(L_{P A e q T}\right)$ podczas realizowania badań na postoju oraz przejazdu ze stałą prędkością. Maksymalny poziom dźwięku skorygowany charakterystyką A $\left(L_{p A F \max }\right)$ dla oceny hałasu podczas fazy przyspieszania i hamowania [4].
PN-EN ISO 3095 Kolejnictwo. Akustyka. Pomiar hałasu emitowanego przez pojazdy szynowe. Norma ta określa warunki oraz metodyki wykonania pomiarów hałasu zewnętrznego pojazdów szynowych. Zakres normy obejmuje wytyczne dotyczące następujących sytuacji pomiarowych: przejazd pojazdu ze stałą prędkościa, hamowanie i przyspieszanie oraz pomiar na postoju. Wielkościami mierzonymi są następujące wielkości:

W przypadku pomiarów przejazdu pojazdów szynowych mikrofony pomiarowe powinny być zlokalizowane $\mathrm{z}$ dwóch storn pojazdu $\mathrm{w}$ dwóch odległościach : 7,5 m i $25 \mathrm{~m}$ od osi toru na wysokości $1,2 \mathrm{~m}$ i 3,5 m powyżej główki szyny. Na rysunku 2 przedstawiono schemat lokalizacji mikrofonów pomiarowych podczas przejazdu pojazdu szynowego.

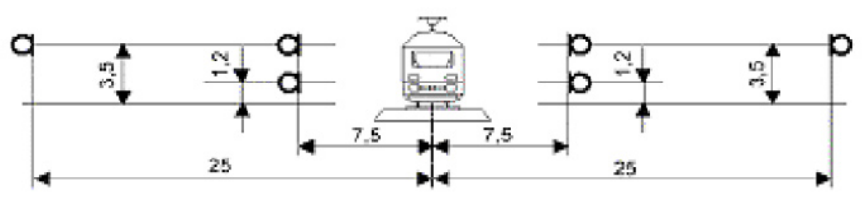

Rys. 2 Rozmieszczenie mikrofonów pomiarowych podczas przejazdu pojazdu szynowego [5]

Norma określa także prędkości jazdy pociagów, przy których należy wykonywać pomiary dla oceny hałasu podczas przejazdu pociagu ze stałą prędkością. Zawierają się one w przedziale od 20 do $350 \mathrm{~km} / \mathrm{h}$. Wybór prędkości jazdy zależy od typu pociagu. Dla każdego typu pociagu zalecane jest wykonanie pomiarów hałasu dla dwóch przypadków: przejazdu z maksymalną prędkością $V_{\max }$ i prędkością wskazaną. Prędkości z którymi należy zrealizować drugi pomiar zawierają się w następujących przedziałach:

- $\mathrm{V}_{\max } \geq 200 \mathrm{~km} / \mathrm{h}$ zalecaną prędkością pomiaru jest $160 \mathrm{~km} / \mathrm{h}$ dodatkowo należy wykonać także pomiar przy prędkości $80 \mathrm{~km} / \mathrm{h}$

- $80 \mathrm{~km} / \mathrm{h}<\mathrm{V}_{\max }<200 \mathrm{~km} / \mathrm{h}$ badania powinny być wykonane z prędkością $\mathrm{v}=80 \mathrm{~km} / \mathrm{h}$

- $\mathrm{V}_{\text {max }} \leq 80 \mathrm{~km} / \mathrm{h}$ badania przeprowadza się $\mathrm{z}$ $\mathrm{v}=40 \mathrm{~km} / \mathrm{h}$.

W przypadku oceny hałasu pociagu podczas fazy przyspieszania i hamowania prędkości przy których należy rejestrować poziomy dźwięku norma definiuje następująco: od 0 do $30 \mathrm{~km} / \mathrm{h}$ dla fazy przyspieszania i od $30 \mathrm{~km} / \mathrm{h}$ do zatrzymania dla fazy hamowania.

Pomiary na postoju powinny być realizowane w odległości 7,5 m od osi toru na wysokości $1,2 \mathrm{~m}$ powyżej główki szyny. Na rysunku 3 przedstawiono przykład rozmieszczenia punktów pomiarowych podczas oceny hałasu pojazdów szynowych na postoju.

Odległości pomiędzy równoległymi do ścian bocznych pojazdu mikrofonami powinny zawierać się od 3 do $5 \mathrm{~m}$ tak aby z każdej strony pojazdu szynowego zlokalizować można trzy punkty pomiarowe. Czas pomiaru w każdym z punktów powinien wynosić co 
najmniej $20 \mathrm{~s}$. Podczas pomiarów urządzenia, które mogą działać gdy pojazd stoi powinny być uruchomione.

Wszystkie badania hałasu pojazdów szynowych (na postoju, podczas przejazdu ze stałą prędkością oraz podczas fazy przyspieszania i hamowania) powinny być poprzedzone pomiarami tła akustycznego. W trakcie wykonywania pomiarów hałasu emitowanego przez pojazdy szynowe powinny być również zachowane następujące warunki odnoszące się do środowiska, pojazdu i toru:

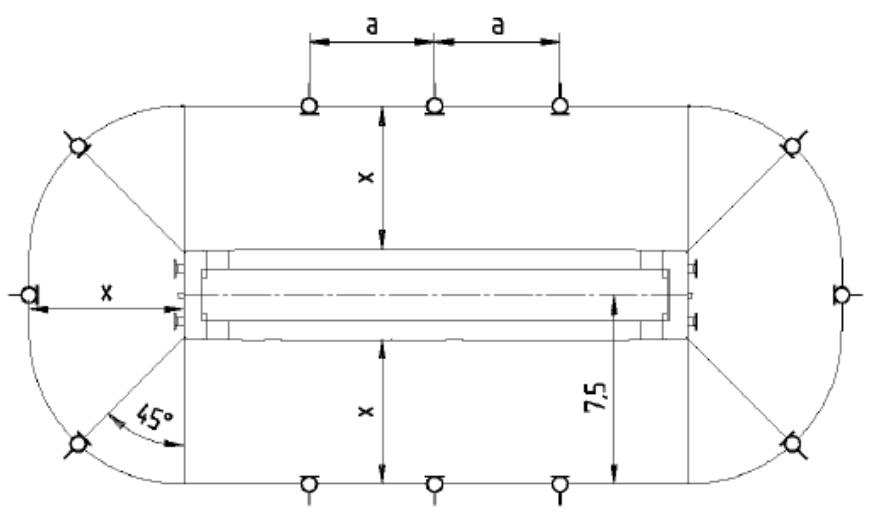

Rys. 3 Schemat rozmieszczenia mikrofonów pomiarowych dla oceny hałasu pojazdów szynowych na postoju [5]

Teren wokół miejsca w którym odbywają się pomiary powinien być płaski bez powierzchni mogących odbijać dźwięk ponadto badania powinny być prowadzone przy braku opadów atmosferycznych i prędkości wiatru do $5 \mathrm{~m} / \mathrm{s}$. Przejazdy badanych pojazdów szynowych powinny obywać się bez pasażerów, przy zamkniętych drzwiach i oknach. Nawierzchnia kolejowa do oceny hałasu to tor $\mathrm{z}$ niecką podsypkową oraz drewnianymi lub żelbetowymi podkładami pozbawiony osłon. Tor na odcinku pomiarowym powinien być spawany oraz pozbawiony widocznych wad powierzchniowych [5].

Techniczna Specyfikacja Interoperacyjności Podsystem: Tabor kolejowy dla kolei konwencjonalnych Zakres: Halas Aspekt: Halas emitowany przez wagony towarowe, lokomotywy, zespoły trakcyjne oraz wagony pasażerskie ma zastosowanie do nowego i odnowionego jaki i zmodernizowanego taboru kolejowego. Zawiera określone wartości poziomów dopuszczalnych dla oceny hałasu stacjonarnego, ruszania, przejazdu pojazdów szynowych oraz hałasu wewnątrz kabiny maszynisty. Obejmuje procedury pomiaru i poziomy dopuszczalne dla następujących typów pojazdów: wagonów towarowych i pasażerskich, lokomotyw oraz maszyn torowych. Procedury pomiaru zawarte $\mathrm{w}$ tym dokumencie opierają się na normie PN-EN ISO 3095 Kolejnictwo. Akustyka. Pomiar hałasu emitowanego przez pojazdy szynowe.
W dokumencie określono następujące wartości dopuszczalne hałasu generowanego przez pojazdy szynowe na postoju:

- wagony towarowe i pasażerskie $65 \mathrm{~dB}$

- lokomotywy elektryczne i spalinowe oraz i maszyny torowe $\mathrm{z}$ napędem elektrycznym i spalinowym $75 \mathrm{~dB}$

- zespoły trakcyjne $\mathrm{z}$ napędem elektrycznym $68 \mathrm{~dB}$

- zespoły trakcyjne z napędem spalinowym $73 \mathrm{~dB}$. W zakresie oceny hałasu przejazdu TSI ustala następujące wartości dopuszczalne:

- lokomotywy elektryczne i spalinowe oraz maszyny torowe $\mathrm{z}$ napędem elektrycznym i spalinowym $85 \mathrm{~dB}$

- zespoły trakcyjne $\mathrm{z}$ napędem elektrycznym $81 \mathrm{~dB}$

- zespoły trakcyjne z napędem spalinowym $82 \mathrm{~dB}$

- wagony pasażerskie $80 \mathrm{~dB}$

- nowe wagony towarowe $82-85 \mathrm{~dB}$

- odnowione lub zmodernizowane wagony towarowe $84-87 \mathrm{~dB}$.

Podczas oceny hałasu ruszania zmierzone poziomy dźwięku nie powinny przekroczyć następujących poziomów dopuszczalnych:

- lokomotywy elektryczne o P $<4500 \mathrm{~kW}$ na kole $82 \mathrm{~dB}$

- lokomotywy elektryczne o P ? $4500 \mathrm{~kW}$ oraz maszyny torowe $\mathrm{Z}$ napędem elektrycznym $85 \mathrm{~dB}$

- lokomotywy spalinowe o $\mathrm{P}<2000 \mathrm{~kW}$ na wale $86 \mathrm{~dB}$

- lokomotywy spalinowe o $\mathrm{P} \geq 2000 \mathrm{~kW}$ na wale oraz maszyny torowe $\mathrm{z}$ napędem spalinowym $89 \mathrm{~dB}$

- zespoły trakcyjne $\mathrm{z}$ napędem elektrycznym $82 \mathrm{~dB}$

- zespoły trakcyjne $\mathrm{z}$ napędem spalinowym o $\mathrm{P}<500 \mathrm{~kW} /$ silnik $83 \mathrm{~dB}$

- zespoły trakcyjne $\mathrm{z}$ napędem spalinowym o $\mathrm{P} \geq 500 \mathrm{~kW} /$ silnik $85 \mathrm{~dB}$.

Wewnątrz kabiny maszynisty lokomotyw elektrycznych i spalinowych poziom dopuszczalny hałasu nie może przekroczyć $95 \mathrm{~dB}$ na postoju podczas emitowania sygnału ostrzegawczego. Podczas jazdy przy prędkościach mniejszych niż $190 \mathrm{~km} / \mathrm{h}$ na terenie otwartym bez wewnętrznych i zewnętrznych sygnałów ostrzegawczych poziom dopuszczalny nie może przekroczyć $78 \mathrm{~dB}$ [2].

Rozporządzenie Ministra Infrastruktury w sprawie zakresu warunków, terminów i sposobu przeprowadzania badań technicznych tramwajów i trolejbusów oraz jednostek wykonujących te badania. W rozporzadzeniu tym zawarto procedury pomiaru poziomu sygnału dźwiękowego tramwajów oraz hałasu zewnętrznego tramwajów na postoju i podczas jazdy. 
Wszystkie procedury pomiaru hałasu w tym rozporządzeniu bazują na normie PN-EN ISO 3095:2005 Kolejnictwo. Akustyka. Pomiar hałasu emitowanego przez pojazdy szynowe.

Podczas pomiarów hałasu zewnętrznego tramwaju mikrofony pomiarowe powinny zostać zlokalizowane na wysokości $1,2 \mathrm{~m}$ nad powierzchnią główki szyny $\mathrm{z}$ zachowaniem następujących kryteriów co do odległości pomiarowych: $7,5 \mathrm{~m}$ od osi toru podczas jazdy tramwaju i $6 \mathrm{~m}$ dla pomiarów stacjonarnych. W przypadku badania poziomu dźwięku sygnału dźwiękowego tramwaju odległość usytuowania mikrofonu powinna wynosić $3 \mathrm{~m}$ licząc od najbardziej wysuniętego do przodu punktu ściany czołowej.

Pomiary stacjonarne powinny obejmować cały tramwaj. W każdym punkcie pomiarowym czas pomiaru powinien wynosić co najmniej $20 \mathrm{~s}$. W przypadku wykonywania pomiarów hałasu $\mathrm{w}$ ruchu tramwaj powinien poruszać się z prędkością $50 \mathrm{~km} / \mathrm{h}$. W każdym punkcie pomiarowym należy wykonać co najmniej 3 serie pomiarowe.

Wielkością mierzoną dla oceny hałasu zewnętrznego jest równoważny poziom dźwięku $L_{\text {Aeq }}$, a dla sygnału dźwiękowego tramwaju maksymalny poziom dźwięku $L_{\text {AFmax }}$ [7].

Rozporządzenie Ministra Infrastruktury w sprawie warunków technicznych tramwajów i trolejbusów oraz zakresu ich niezbędnego wyposażenia. W rozporządzeniu tym zawarto poziomy dopuszczalne odnoszące się do pomiarów hałasu tramwajów w środowisku. Tramwaj powinien być tak zbudowany, wyposażony i utrzymany aby poziom dźwięku na zewnątrz nie przekraczał: $80 \mathrm{~dB}$ - podczas przejazdu ze stałą prędkością $50 \mathrm{~km} / \mathrm{h}$ i $64 \mathrm{~dB}$ - na postoju.

W przypadku sygnału dźwiękowego poziom dźwięku nie powinien przekraczać $85 \mathrm{~dB}$ dla tramwajów wyprodukowanych po dniu 31 grudnia 1974 a przed dniem 1 lipca 2011 r. i $90 \mathrm{~dB}$ dla tramwajów wyprodukowanych po dniu 30 czerwca 2011 r. [8].

\section{Porównanie klimatu akustycznego panującego we wnętrzu wybranych typów pojazdów szyno- wych podczas jazdy}

Dokonano oceny klimatu akustycznego wewnątrz następujących pojazdów szynowych: w kabinie maszynisty lokomotyw elektrycznych serii ET22 i EU07, w wagonach bezprzedziałowych 1 i 2 klasy typu 152A i $154 \mathrm{Aa}$, wagonach z przedziałami 1 i 2 klasy typu $145 \mathrm{Ab}$ oraz $w$ wagonach tramwajowych typu $105 \mathrm{~N} / 105 \mathrm{Na}$ i Tatra. Wszystkie pomiary wykonano podczas normalnej pracy przewozowej.

W lokomotywach elektrycznych serii EU07 i ET22 rejestrowano poziomy dźwięku podczas jazdy z zadanymi prędkościami. Lokomotywy ET22 poruszały się $\mathrm{z}$ prędkością: $\mathrm{v}=60 \mathrm{~km} / \mathrm{h}, \quad \mathrm{v}=80 \mathrm{~km} / \mathrm{h} \quad \mathrm{i}$ $\mathrm{v}=100 \mathrm{~km} / \mathrm{h}$. Natomiast lokomotywy EU07 z prędkościami v $=80 \mathrm{~km} / \mathrm{h}, \mathrm{v}=100 \mathrm{~km} / \mathrm{h} \mathrm{i} \mathrm{v}=120 \mathrm{~km} / \mathrm{h}$.
Zestawienie uzyskanych wyników zawarto w tabelach 2 i 3. Tabela 2 dotyczy lokomotyw ET22 natomiast tabela 3 obejmuje wyniki zarejestrowane w lokomotywach serii EU07 [3].

Poziom dźwięku $L_{A e q}[\mathrm{~dB}]$ w kabinie maszynisty lokomotywy ET22 [3]

Tabela 2

\begin{tabular}{|c|c|c|c|}
\hline \multirow{2}{*}{$\begin{array}{c}\text { Seria } \\
\text { i nr lokomotywy }\end{array}$} & \multicolumn{3}{|c|}{ Prędkość jazdy [km/h] } \\
\cline { 2 - 4 } & $\mathbf{6 0}$ & $\mathbf{8 0}$ & $\mathbf{1 0 0}$ \\
\hline ET22-384 & 77 & 77 & 78 \\
\hline ET22-578 & 77 & 78 & 78 \\
\hline ET22-642 & 78 & 80 & 79 \\
\hline
\end{tabular}

W przebadanych lokomotywach ET22 podczas jazdy zmierzone równoważne poziomy dźwięku zawierały się w przedziale $77-80 \mathrm{~dB}$. Najniższe wartości równoważnego poziomu dźwięku uzyskano w lokomotywach ET22-384 i ET22-578 w badanych pojazdach równoważne poziomy dźwięku nie przekroczyły $79 \mathrm{~dB}$. Najwyższe poziomy zarejestrowano w lokomotywie ET22-642 jazda lokomotywy z prędkościami powyżej $60 \mathrm{~km} / \mathrm{h}$ powodowała, że równoważne poziomy dźwięku przekraczały poziom $79 \mathrm{~dB}$.

Poziom dźwięku $L_{A e q}[\mathrm{~dB}]$ w kabinie maszynisty lokomotywy EU07 [3]

Tabela 3

\begin{tabular}{|c|r|r|r|}
\hline \multirow{2}{*}{$\begin{array}{c}\text { Seria } \\
\text { i nr lokomotywy }\end{array}$} & \multicolumn{3}{|c|}{ Prędkość jazdy $[\mathbf{k m} / \mathbf{h}]$} \\
\cline { 2 - 4 } & \multicolumn{1}{|c|}{$\mathbf{8 0}$} & \multicolumn{1}{c|}{$\mathbf{1 0 0}$} & \multicolumn{1}{c|}{$\mathbf{1 2 0}$} \\
\hline EU07-151 & 78 & 79 & 81 \\
\hline EU07-229 & 76 & 78 & 79 \\
\hline EU07-360 & 76 & 77 & 77 \\
\hline
\end{tabular}

W przypadku lokomotyw serii EU07 zmierzone równoważne poziomy dźwięku zawierały się w przedziale od $77-81 \mathrm{~dB}$. Najniższe poziomy dźwięku zarejestrowano w lokomotywie EU07-360 zmierzone równoważne poziomy dźwięku nie przekroczyły $77 \mathrm{~dB}$ niezależnie z jaką prędkością poruszała się lokomotywa. Najwyższe równoważne poziomy dźwięku uzyskano w lokomotywie EU07-151. Przy prędkości $120 \mathrm{~km} / \mathrm{h}$ równoważny poziom dźwięku przekroczył $81 \mathrm{~dB}$.

W wagonach pasażerskich oceny hałasu dokonano podczas przejazdu pociagu typu Intercity na trasie Warszawa - Poznań. Podczas pomiarów nie rejestrowano prędkości z jaką poruszał się pociąg. Do badań wybrano po jednym wagonie następujących typów:

- wagon bezprzedziałowy 1 klasy (wagon ostatni w składzie) typu 152A,

- wagon bezprzedziałowy 2 klasy (pierwszy w składzie) typu 154Aa,

- wagon z przedziałami 1 klasy (wagon w środku składu) typu $145 \mathrm{Ab}$,

- wagon z przedziałami 2 klasy (wagon w środku składu) typu 145Ab. 
We wszystkich badanych wagonach zlokalizowano 5 punktów pomiarowych rozmieszczonych w następujących miejscach: dwa punkty znajdowały się na korytarzu przy wejściu do wagonu - mikrofon umieszczono na wysokości $1,6 \mathrm{~m}$ od poziomu podłogi, trzy punkty w części pasażerskiej wagonu w jego osi wzdłużnej, tzn. na czopami skrętu wózków i w środku wagonu. W punktach tych mikrofony umieszczono na wysokości $1,2 \mathrm{~m}$ od poziomu podłogi. Wyniki uzyskanych badań zamieszono w tabeli 4 .

Wykonane badania wykazały, że w części pasażerskiej nad pierwszym i drugim wózkiem oraz na środku wagonu zmierzone równoważne poziomy dźwięku zwierały się w przedziale od $58-79 \mathrm{~dB}$. W wagonach bezprzedziałowych najlepszy klimat akustyczny panował w wagonie 2 klasy. Uzyskane wyniki pomiarów nie przekroczyły $68 \mathrm{~dB}$. Najwyższy poziom dźwięku $78 \mathrm{~dB}$ zarejestrowano nad pierwszym wózkiem w wagonie pierwszej klasy.

W przypadku pomiarów $\mathrm{w}$ wagonach $\mathrm{z}$ przedziałami najniższy poziom dźwięku $58 \mathrm{~dB}$ uzyskano w przedziale środkowym $\mathrm{w}$ wagonie pierwszej klasy. Najwyższe poziomy zarejestrowano $\mathrm{w}$ wagonie drugiej klasy: w przedziale środkowym i nad drugim wózkiem. Zmierzone $w$ tych miejscach poziomy równoważne przekroczyły $67 \mathrm{~dB}$. Na korytarzach najwyższe równoważne poziomy dźwięku uzyskano w wagonach pierwszej klasy. W wagonach bezprzedziałowych uzyskano $80-93 \mathrm{~dB}$ a w wagoach z przedziałami $65-$ $94 \mathrm{~dB}$.

Ocenie hałasu wewnętrznego poddano także wagony tramwajowe. Do badań wybrano wagony tramwajowe typu 105N/105Na i Tatra RT6-N1. W każdym $\mathrm{z}$ tramwajów pomiarów dokonano $\mathrm{w}$ dwóch punktach pomiarowych: z przodu i w środku tramwaju. Mikrofon umieszczono na wysokości $700 \mathrm{~mm}$ nad po- wierzchnią siedzenia w płaszczyźnie symetrii siędzenia, natomiast w środku tramwaju mikrofon umieszczony był na wysokości $1600 \mathrm{~mm}$ nad powierzchnią podłogi. W tabeli 5 przedstawiono wyniki zmierzonych równoważnych poziomów dźwięku w wnętrzu dwóch typów tramwajów: $105 \mathrm{~N} / 105 \mathrm{Na}$ i Tatra RT6 [10].

Wykonane badania wykazały, że w wagonach typu $105 / 105 \mathrm{Na}$ zmierzone równoważne poziomy dźwięku z przodu i na środku pojazdu przekroczyły poziom $70 \mathrm{~dB}$ już przy prędkości $10 \mathrm{~km} / \mathrm{h}$. Przy prędkości $45 \mathrm{~km} / \mathrm{h}$ uzyskane wyniki przekroczyły $81 \mathrm{~dB}$.

W przypadku tramwajów typu Tatra równoważne poziomy dźwięku przekraczające $70 \mathrm{~dB}$ zarejestrowano przy prędkości $30 \mathrm{~km} / \mathrm{h}$ z przodu tramwaju. Wzrost prędkości do $35 \mathrm{~km} / \mathrm{h}$ spowodował, że zarówno $\mathrm{z}$ przodu jak i w środku pojazdu poziomy równoważne przekraczają $72 \mathrm{~dB}$.

\section{Podsumowanie}

$\mathrm{W}$ artykule omówiono wybrane przepisy związane $\mathrm{z}$ oceną hałasu pojazdów szynowych oraz przedstawiono wyniki pomiarów hałasu we wnętrzu wybranych typów pojazdów szynowych podczas jazdy. Do badań wybrano kabinę maszynisty w lokomotywach elektrycznych ET22 i EU07, wagony pasażerskie z przedziałami i bezprzedziałów pierwszej i drugiej klasy oraz wagony tramwajowe. Na podstawie przeprowadzonych badań sformułowano następujące wnioski:

- W przedziale maszynisty lokomotyw elektrycznych ET22 i EU07 podczas jazdy z prędkościami powyżej $80 \mathrm{~km} / \mathrm{h}$ rejestrowane równoważne poziomy dźwięku nie przekroczyły poziomu $80 \mathrm{~dB}$.

Poziom dźwięku $L_{A e q}[\mathrm{~dB}]$ zarejestrowane w wagonach pasażerskich

Tabela 4

\begin{tabular}{|l|l|c|c|c|c|c|}
\hline & & \multicolumn{5}{|c|}{ Polożenie punktów pomiarowych } \\
\hline \multirow{2}{*}{ Typ wagonu } & $\begin{array}{l}\text { Klasa } \\
\text { wagonu }\end{array}$ & $\begin{array}{c}\text { korytarz wejście } \\
\text { do wagonu }\end{array}$ & 1 wózek & $\begin{array}{c}\text { środek } \\
\text { wagonu }\end{array}$ & 2 wózek & $\begin{array}{c}\text { korytarz wejście } \\
\text { do wagonu }\end{array}$ \\
\hline $\begin{array}{l}\text { Wagony } \\
\text { bezprzedzia- } \\
\text { łowe }\end{array}$ & Klasa 1 & 93 & 79 & 66 & 66 & 80 \\
\cline { 2 - 7 } & Klasa 2 & 63 & 63 & 62 & 68 & 84 \\
\hline $\begin{array}{l}\text { Wagony z } \\
\text { przedziałami }\end{array}$ & Klasa 1 & 65 & 60 & 58 & 72 & 94 \\
\cline { 2 - 7 } & Klasa 2 & 71 & 64 & 67 & 67 & 87 \\
\hline
\end{tabular}

Równoważne poziomy dźwięku $L_{\text {Aeq }} \mathrm{w}$ [dB] zarejestrowane wewnątrz wagonów tramwajowych [10] Tabela 5

\begin{tabular}{|l|l|c|c|c|c|c|c|c|c|}
\hline Typ tramwaju & \multicolumn{1}{|c|}{ Prędkość $[\mathbf{k m} / \mathbf{h}]$} & $\mathbf{1 0}$ & $\mathbf{1 5}$ & $\mathbf{2 0}$ & $\mathbf{2 5}$ & $\mathbf{3 0}$ & $\mathbf{3 5}$ & $\mathbf{4 0}$ & $\mathbf{4 5}$ \\
\hline \multirow{2}{*}{$105 \mathrm{~N} / 105 \mathrm{Na}$} & przód tramwaju & 70 & 70 & 71 & 72 & 72 & 74 & 75 & 81 \\
\cline { 2 - 10 } & środek tramwaju & 70 & 71 & 72 & 73 & 74 & 75 & 76 & 82 \\
\hline \multirow{2}{*}{ Tatra RT6 } & przód tramwaju & 65 & 65 & 66 & 68 & 70 & 72 & 76 & 76 \\
\cline { 2 - 10 } & środek tramwaju & 64 & 65 & 65 & 67 & 68 & 72 & 74 & 75 \\
\hline
\end{tabular}


- W wagonach pasażerskich z przedziałami i bezprzedziałowymi pierwszej i drugiej klasy zmierzone równoważne poziomy dźwięku zawierały się między 58-94 dB. Najniższe wartości równoważnego poziomu dźwięku uzyskano w wagonach z przedziałami $58-72 \mathrm{~dB}$, natomiast $\mathrm{w}$ wagonach bezprzedziałowych uzyskane wyniki badań zawierały się w przedziale $62-79 \mathrm{~dB}$. Na korytarzach $\mathrm{w}$ badanych wagonach równoważne poziomy dźwięku przekroczyły poziom $94 \mathrm{~dB}$.

- Zrealizowane badania hałasu we wnętrzu tramwajów typu $105 \mathrm{~N} / 105 \mathrm{Na}$ i Tatra RT6 wykazały, że poziom $70 \mathrm{~dB}$ został osiagnięty podczas przejazdu tramwajów $105 \mathrm{~N} / 105 \mathrm{Na} \mathrm{z}$ prędkością $10 \mathrm{~km} / \mathrm{h}$ a tramwajów typu Tatra RT6 z prędkością powyżej $30 \mathrm{~km} / \mathrm{h}$.

Praca naukowa finansowana ze środków budżetowych na naukę w latach 2010 - 2013 jako projekt badawczy pt „Ocena i modelowanie hałasu zewnętrznego i wewnętrznego środków transportu miejskiego".

\section{Bibliografia}

[1] Czechyra B., Aktywność wibroakustyczna pojazdu szynowego-koncepcja nowego narzędzia diagnostycznego. $W$ Materiały Seminarium Zakładu Pojazdów Szynowych Poznań 19.06.2012 Materiaty niepublikowane.

[2] Decyzja Komisji z dnia 4 kwietnia 2011 r dotyczqca Technicznej Specyfikacji Interoperacyjności odnoszacej sie do podsystemu ,,Tabor kolejowy-hatas” transeuropejskiego systemu kolei
[3] Orczyk M., Tomaszewski F., Ocena poziomu hałasu w kabinie maszynisty lokomotyw elektrycznych podczas

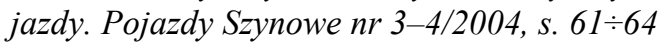

[4] PN-EN ISO 3381 Kolejnictwo. Akustyka. Pomiar hałasu wewnatrz pojazdów szynowych.

[5] PN-EN ISO 3095 Kolejnictwo. Akustyka. Pomiar hałasu emitowanego przez pojazdy szynowe.

[6] Rozporzqdzenie Ministra Środowiska z dnia 14 czerwca $2007 r$ w sprawie dopuszczalnych poziomów hałasu $w$ środowisku Dz. U. nr 120, poz. 826.

[7] Rozporzqdzenie Ministra Infrastruktury $z$ dnia 28 stycznia $2011 \mathrm{r} w$ sprawie zakresu, warunków, terminów $i$ sposobu przeprowadzania badań technicznych tramwajów $i$ trolejbusów oraz jednostek wykonujacych te badania. Dz. U. nr 65, poz. 343.

[8] Rozporzadzeni Ministra Infrastruktury z dnia 2 marca $2011 r w$ sprawie warunków technicznych tramwajów $i$ trolejbusów oraz zakresu ich niezbędnego wyposażenia. Dz. U. nr 65, poz. 344.

[9] Rozporzqdzenie Ministra Środowiska z dnia 16 czerwca $2011 r w$ sprawie wymagań $w$ zakresie prowadzenia pomiarów poziomów substancji lub energii $w$ środowisku przez zarzadzajacego droga, liniq kolejowa, liniq tramwajowa, lotniskiem lub portem Dz. U. nr 140, poz. 824 .

[10] Tomaszewski F., OrczykM., Ocena poziomu hałasu wewnatrz tramwajów na podstawie badań. Pojazdy Szynowe $n r$ 4/2007, s. $1 \div 7$

[11] Wojciechowska E., Analiza metod szacowania poziomu dźwięku pojazdów szynowych. Rozprawa doktorska, Politechnika Poznańska Wydziat Maszyn Roboczych i Transportu, Poznań 2008. 